\title{
DA ESCRITA DA MEMÓRIA À MEMÓRIA DO BELO: A CRÔNICA DE MACHADO DE ASSIS
}

\author{
Alex Sander Luiz Campos \\ Mestrando em Literatura Brasileira do Programa de Pós-Graduação em Estudos Literários / \\ UFMG. (bolsista do CNPq)
}

\begin{abstract}
RESUMO
Recorrendo a crônicas de duas séries machadianas, a teóricos como Walter Benjamin e Maurice Halbwachs e a estudiosos da crônica, este trabalho ${ }^{1}$ propõe reflexões sobre a memória baseadas na crônica machadiana, seja em sua condição específica de gênero como "memória escrita", seja quando reflete sobre a memória do belo.
\end{abstract}

\section{PALAVRAS-CHAVE}

Crônica, memória, Machado de Assis, "Bons dias!", "A Semana”

É significativo o título de uma das obras mais emblemáticas do pintor catalão Salvador Dalí: A persistência da memória, pequeno óleo sobre tela pertencente ao acervo do Museu de Arte Moderna de Nova York. ${ }^{2}$ Lá estão representadas, no estilo surrealístico de seu autor, ao menos duas das maiores preocupações humanas: tempo e memória, questões sempre presentes na filosofia, na literatura, nas artes plásticas, etc. Sob o efeito de uma forte luminosidade, os relógios em processo de derretimento - os "relógios moles", designação também comum ao quadro - parecem ressaltar a dimensão fugidia do tempo, revelando o interesse daliano pelas descobertas da ciência moderna, especialmente o estudo einsteiniano da relatividade, que coloca em causa a ideia de espaço e tempo fixos.

\footnotetext{
${ }^{1}$ Uma primeira versão deste texto (com o título "Considerações sobre a memória na crônica machadiana") foi contemplada com o $2^{\circ}$ lugar no I Concurso TRAVESSIA: Literatura e Pesquisa, realizado pelo Diretório Acadêmico Carlos Drummond de Andrade e Diretoria da Faculdade de Letras da UFMG. Versão anterior foi publicado na revista dEsEnrEdoS (n. 11, out.-dez. 2011), sob o título "Reflexões sobre a memória na crônica de Machado de Assis".

${ }^{2}$ DALÍ. The persistence of memory.
} 
O quadro daliano foi finalizado em 1931, porém, mais de quatro décadas antes, no Oitocentos brasileiro, já era possível encontrar uma "pintura" com muitos pontos de contato com a do pintor da Catalunha. Trata-se da primeira crônica de "Bons dias!", série publicada por Machado de Assis na Gazeta de Notícias nos anos de 1888 e 1889. A crônica em questão é do dia 5 de abril de 1888 , e um fragmento é transcrito a seguir:

Portanto, bico calado. No mais é o que se está vendo; cá virei uma vez por semana, com o meu chapéu na mão, e os bons dias na boca. Se lhes disser já, que não tenho papas na língua, não me tomem por homem despachado, que vem dizer coisas amargas aos outros. Não, senhor; não tenho papas na língua, e é para vir a tê-las que escrevo. Se as tivesse, engolia-as e estava acabado. Mas aqui está o que é; eu sou um pobre relojoeiro que, cansado de ver que os relógios deste mundo não marcam a mesma hora, descri do ofício. A única explicação dos relógios era serem iguaizinhos, sem discrepância; desde que discrepam, fica-se sem saber nada, porque tão certo pode ser o meu relógio, como o do meu barbeiro. ${ }^{3}$

É certo que Dalí não teve conhecimento da crônica, porque só na década de 1950 a série seria atribuída a Machado de Assis e receberia a publicação em livro - quando de sua publicação na Gazeta, a série saíra sob anonimato. ${ }^{4}$ Mesmo assim, as duas "pinturas" de relógios em discrepância, relógios que não se acertam, estabelecem interessante diálogo. $\mathrm{O}$ cronista de "Bons dias!", assim como aparece nesse texto de apresentação da série, é um exrelojoeiro descrente do ofício, dada a impossibilidade da apreensão de um tempo fixo. Como no quadro de Dalí, é a memória que persiste ante o derretimento dos relógios. O objetivo deste trabalho é, pois, tecer reflexões sobre a memória na crônica de Machado de Assis, fazendo referência a duas contribuições do autor de Dom Casmurro (1900) à imprensa carioca: “Bons dias!", a série já citada, e a que foi publicada posteriormente, no mesmo jornal, “A Semana" (1892-1897).

Conforme veremos, o estudo da memória na crônica machadiana se justifica pelo interesse de Joaquim Maria em relação a esse tema e à própria concepção do gênero crônica. A recorrência a políticos e suas histórias será o recorte necessário para a análise de como se dá o processo de memória e esquecimento naqueles textos. Por fim, será tratado um tema caro ao cronista: a memória do belo, o poder da força, assim como a relação necessária entre memória individual e memória coletiva, tal como propôs o sociólogo francês Maurice Halbwachs.

\footnotetext{
${ }^{3}$ ASSIS. Bons dias!, p. 80, grifo do autor.

${ }^{4}$ GRANJA. Machado de Assis cronista: primeiros anos, p. 600. A primeira edição de "Bons dias!” em livro é de 1956, pela Civilização Brasileira, com organização de Raimundo Magalhães Júnior.
} 
O interesse de Machado de Assis pela memória é inquestionável - ou, então, correríamos o risco de ignorar suas obras-primas, passando pela experiência das memórias de um “defunto autor" em Memórias póstumas de Brás Cubas (1881) ou pelas memórias de um narrador não confiável como Bento Santiago, em Dom Casmurro. A presença da memória é notável mais uma vez em seu último romance, Memorial de Aires (1908). E isso só para ficar nos romances, dos gêneros em que escreveu Machado o que mais conta com estudos e crítica. Sobre a sedução que a memória exercia sobre o Bruxo do Cosme Velho, Sávio Péres e Marina Massimi afirmam que o mestre brasileiro

elaborou em sua obra uma descrição riquíssima, do ponto de vista qualitativo, de tal fenômeno, tratado como uma experiência vivida e não enquanto fenômeno redutível às suas bases materiais. Devido à agudeza de expressão do autor, Machado pôde se embrenhar nos labirintos da memória, revelando com extrema clareza, os seus diferentes aspectos. A memória, portanto, não é compreendida por si só, isto é, como uma gaveta onde simplesmente se guardam lembranças cristalizadas, mas sim em dinâmica com a totalidade vital do homem. ${ }^{5}$

Ao tratarmos das memórias de políticos na crônica machadiana, a "experiência vivida" e a dinâmica a que se referem Péres e Massimi em relação ao conceito de memória em Machado poderão ser exemplificadas, pensadas justamente com o "recordar" e o "esquecer". Por ora, ainda discorrendo sobre o lugar da memória na obra de Machado de Assis, vale lembrar o peso que tal discussão tem na constituição de sua Biblioteca. Novamente, uma citação de Péres e Massimi:

Podemos observar, em diferentes âmbitos, que Machado de Assis teve um grande interesse pela memória. De fato, o restando do acervo da Biblioteca de Machado de Assis indica, pelos livros ali encontrados, que Machado de Assis muito se interessava pela psiquiatria e pela psicologia, e que tinha um especial interesse na faculdade da memória. ${ }^{6}$

O interesse especial de Machado pela faculdade da memória também pode ser comprovado por sua produção de crônicas, afinal, foram quatro décadas de contribuição à imprensa, sobretudo - mas não exclusivamente - a fluminense. Desta forma, o cronista configura-se como narrador do tempo vivido por ele e por seus leitores, com todas as transformações e rupturas. ${ }^{7}$ De acordo com Davi Arrigucci Júnior, é a própria relação com o tempo que define o gênero crônica: "Lembrar e escrever: trata-se [a crônica] de um relato em

\footnotetext{
${ }^{5}$ PÉRES; MASSIMI. O conceito de memória na obra de Machado de Assis, p. 32.

${ }^{6}$ PÉRES; MASSIMI. O conceito de memória na obra de Machado de Assis, p. 20.

${ }^{7}$ NEVES. Uma escrita do tempo: memória, ordem e progresso nas crônicas machadianas, p. 77.
} 
permanente tensão com o tempo, de onde tira, como memória escrita, sua matéria principal, o que fica do vivido." ${ }^{8}$ Para o autor de Enigma e comentário, portanto, a própria constituição da crônica é a memória. Arrigucci Júnior ainda corrobora o fato de que as transformações e rupturas do vivido estão intimamente relacionadas à crônica quando afirma que "é ela própria um fato moderno, submetendo-se aos choques da novidade, ao consumo imediato, às inquietações de um desejo sempre insatisfeito". 9

Além de memória escrita, a crônica também já foi definida como lugar da memória e escrita do tempo. É o que aparece no trecho a seguir, de Margarida de Souza Neves:

Ao reinventar o cotidiano essas narrativas [as crônicas] podem ser consideradas como lugares da memória, no sentido da expressão forçada por Pierre Nora [em Les lieux de la mémoire, obra publicada sob sua direção entre 1894 e 1992]. (...) A crônica, pela própria etimologia chronus/crônica -, é um gênero colado ao tempo. (...) De formas diferenciadas, porque diferente é em cada momento a percepção do tempo histórico, a crônica é sempre de alguma maneira o tempo feito texto, sempre e de formas diversas, uma escrita do tempo. ${ }^{10}$

Se não é possível pensar a crônica sem relacioná-la ao tempo e à memória, também não é possível conceituá-la sem o mínimo de adequação sem fazer referência à imprensa e ao jornalismo. Segundo Samuel Frison e Antônio Sanseverino, em artigo sobre a crônica na trajetória de Clarice Lispector e Hilda Hilst, a relação cúmplice entre jornalismo e literatura é registrada pela crônica. ${ }^{11}$ Essa dependência se explica, de acordo com os referidos autores, pelo fato de o gênero crônica estar vinculado à imprensa escrita, um meio de comunicação de massa. A identidade do cronista, portanto, "é aquela que se constrói entre o intelectual das letras e o repórter, que terminam por se fundir na pessoa que olha para o cotidiano e capta o seu (in)decifrável". 12

Intelectual das letras e repórter foi Machado de Assis já no início da sua carreira na imprensa do Rio de Janeiro, quando era representante do Senado do primeiro jornal diário do país. O relato desse período de sua vida (década de 1860) pode ser encontrado em várias das

\footnotetext{
${ }^{8}$ ARRIGUCCI JÚNIOR. Enigma e comentário: ensaios sobre literatura e experiência, p. 51, grifo nosso.

${ }^{9}$ ARRIGUCCI JÚNIOR. Enigma e comentário: ensaios sobre literatura e experiência, p. 53.

${ }^{10}$ NEVES. Uma escrita do tempo: memória, ordem e progresso nas crônicas machadianas, p. 78-82, grifo da autora.

${ }^{11}$ FRISON; SANSEVERINO. Diálogos sobre a complexidade da crônica na trajetória de Clarice Lispector e Hilda Hilst - duas escritoras - fora de lugar.

${ }^{12}$ FRISON; SANSEVERINO. Diálogos sobre a complexidade da crônica na trajetória de Clarice Lispector e Hilda Hilst - duas escritoras - fora de lugar.
} 
biografias a ele dedicadas. A seguir, segue trecho da biografia escrita por Ayrton Marcondes, publicada em 2008, ano marcado pelo centenário de morte de Machado de Assis:

O seu começo [de Machado de Assis] no jornal foi modesto. Em pouco tempo, porém, assume a crítica literária e a crônica da semana. Mas seria da sua ida para o Senado como representante do Diário do Rio [de Janeiro] que renderia, anos mais tarde, memorável depoimento sobre aquela casa e os homens que faziam política no Brasil de então ["O velho senado", texto publicado em Páginas recolhidas, de 1899]. Há muito de Brasil e brasileiros naquelas páginas que (...) conferem humanidade a nome que conhecemos através das páginas da História. (...) através de seu texto, Machado de Assis lega à posteridade homens com alma, diferentes das fotografias sisudas e das desgastadas lápides onde estão inseridos os seus nomes. ${ }^{13}$

O que Ayrton Marcondes observa sobre "O velho senado" pode, certamente, ser estendido à produção cronística machadiana, em que encontramos um número significativo de textos que recorda políticos do passado ou assuntos afins. ${ }^{14}$ Entretanto, não era a Política com P maiúsculo - que interessava ao mestre carioca, mas políticos e suas histórias, com toda sua humanidade e contradições. É possivelmente difícil ler a relação que estabelece o biógrafo machadiano entre a representação dos políticos por parte da memória e a representação desses mesmos personagens por intermédio das páginas da História sem fazer referência ao pensamento do ensaísta, crítico literário, filósofo e sociólogo Walter Benjamin. Conforme pontua Márcio Seligmann-Silva, Benjamin foi um dos maiores responsáveis pelo despertar do sonho - ou pesadelo - do historicismo de acreditar na possibilidade da restituição e representação total do passado, "tal como ele de fato ocorreu". ${ }^{15}$ Nas crônicas machadianas, conforme veremos, não há a preocupação tão apregoada pelo historicismo de reconstituir o passado em sua perfeição, mas um trabalho com a memória que envolve o fragmentário, as sensações, o esquecimento.

Ainda no que concerne à importância do gênero crônica para a memória, resta marcar a importância do vínculo com a imprensa. Segundo André Leroi-Gourhan, é difícil distinguir a transmissão oral da escrita até o aparecimento da imprensa. Com o texto impresso, o leitor é colocado em presença de uma "memória coletiva enorme, cuja matéria não é mais capaz de

\footnotetext{
${ }^{13}$ MARCONDES. Machado de Assis: exercício de admiração, p. 95.

${ }^{14}$ De acordo com o mapeamento temático de "Bons dias!" por nós realizado, cerca de 22 das 49 crônicas da série tratam de alguma forma de tema ligado à política, seja explorando a "tensão" entre conservadores e liberais, seja comentando o comportamento dos homens públicos ou, ainda, discorrendo sobre a oratória parlamentar, tema frequente em vários dos gêneros em que escreveu Machado. (Para uma interpretação da série "Bons dias!", cf. CAMPOS. Sob o signo de relógios em discrepância: um estudo da série de crônicas "Bons dias!", de Machado de Assis.).

${ }^{15}$ SELIGMANN-SILVA. Reflexões sobre a memória, a história e o esquecimento, p. 60.
} 
fixar integralmente". ${ }^{16} \mathrm{O}$ que ressalta Leroi-Gourhan desse processo é que progressivamente há a exteriorização da memória individual, o que pode ser pensado, segundo nos parece, também no caso da crônica, que possibilitaria a exteriorização da memória no impresso. De parecer semelhante ao do antropólogo francês é o do filósofo de mesma nacionalidade Henri Atlan, para quem a utilização de uma linguagem falada seguida de uma linguagem escrita "é de fato uma extensão fundamental das possibilidades de armazenamento da nossa memória que, graças a isso, pode sair dos limites físicos do nosso corpo para se interpor quer nos outros, quer nas bibliotecas". ${ }^{17}$

No capítulo "O teatro político nas crônicas de Machado de Assis", de Brás Cubas em três versões, Alfredo Bosi nota que havia em Machado de Assis "um gosto acentuado de contar histórias de políticos". ${ }^{18}$ Ainda segundo o autor da História concisa da literatura brasileira,

não são poucas as crônicas em que [Machado de Assis] falou de parlamentares do passado ou seus contemporâneos. Histórias de políticos. Essa preferência leva ainda alguns de seus leitores a pensar que o cronista prestasse tributo à História e à Política. O equívoco é compreensível e devese à intenção louvável de mostrar que um grande escritor é sempre de algum modo participante e, no limite, engajado. (...) Tudo indica, porém, que Machado não acreditava nem esperava nada (ou quase nada) nem da Política nem da História, escritos aqui com iniciais maiúsculas para diferenciá-las do verdadeiro objeto do cronista: políticos e suas histórias. ${ }^{19}$

Se estiver correto Alfredo Bosi em sua leitura da política na crônica de Machado de Assis não como um "louvor" à Política e à História, mas como - agora recorrendo a uma observação de Margarida de Souza Neves, no texto já citado - "lugar da memória", fica evidente que, de certa forma, o cronista brasileiro já antecipa algumas das ideias ou pelo menos atitudes intelectuais do movimento surgido em meados do século 20 e que continuou o percurso de autores que produziram até aquele limiar, como Walter Benjamin e Maurice Halbwachs. Trata-se, com o fim da "referência espacial linear forte" assinalada por Seligmann-Silva, da valorização dos lieux de la mémoire, expressão essencial no trabalho de Pierre Nora. Ainda segundo Márcio Seligmann-Silva, observou-se mais e mais com esse movimento "a ascensão do registro da memória - que é fragmentário, calcado na experiência

\footnotetext{
${ }^{16}$ LEROI-GOURHAN. O gesto e a palavra, p. 69.

${ }^{17}$ ATLAN. Conscience et désirs dans des systèmes auto-organisateurs, p. 449.

${ }^{18}$ BOSI. Brás Cubas em três versões: estudos machadianos, p. 53.

${ }^{19}$ BOSI. Brás Cubas em três versões: estudos machadianos, p. 53, grifos nossos.
} 
individual e da comunidade, no apego a locais simbólicos e não tem como meta a tradução integral do passado". ${ }^{20}$

Como lugar de memória e não de historicismo, a crônica de Machado de Assis não presta tributo à História nem à Política - com iniciais maiúsculas, como destacou Bosi -, mas valoriza a variedade de reminiscências de uma memória individual que não deixa de ser, também, coletiva. É o lugar do fragmentário, dos gestos, da ironia, como pode ser percebido na crônica d"“A Semana" de 2 de junho de 1895, em que o "mote" inicial é a morte de Joaquim Saldanha Marinho (1816-1895), jornalista e político brasileiro. Saldanha Marinho fizera parte da câmara liberal dissolvida por D. Pedro II em 1868, câmara pertencente ao gabinete liberal de Zacarias de Góis (1815-1877). Para historiadores do porte de Joaquim Nabuco e Sérgio Buarque de Holanda, a crise ministerial de 1868 teria marcado o declínio do regime monárquico. ${ }^{21}$ Machado de Assis, segundo Alfredo Bosi, assiste a tudo como observador simpático aos liberais, "pois foi a sua cor ideológica ao longo dos anos [18]60". ${ }^{22}$ Entretanto, questiona o crítico: “o que ficou na sua lembrança e na sua palavra ao retornar àquela sessão momentosa que fechava uma época e abria outra?" 23 É o que nos convida a ler a referida crônica pensando nos "labirintos da memória". ${ }^{24}$

Comentando essa crônica, Alfredo Bosi afirma que a leitura de Machado está ligada aos gestos, aos ritos, aos gritos, às palmas, aos silêncios, à vida, à paixão e à morte dos indivíduos. $^{25}$ É o traço humano que percebe Ayrton Marcondes nos "quadros políticos" pintados por Machado, tão diferentes dos quadros apresentados pela história oficial. ${ }^{26}$ Para Bosi, interessa ao cronista "o ciclo mesmo da existência pelo qual uns vão, outros voltam e todos partem definitivamente", como fica bem ilustrado no comentário machadiano sobre conservadores e liberais: "até que se foram de uma vez, e com uns e outros o Império." O cronista não procura sentido na Política ou na História, o que não cabe em seus textos. Procura, "artista que era, o estilo dos atores políticos; atraíam-no as suas aparições efêmeras, ora risíveis, ora patéticas". ${ }^{27}$

\footnotetext{
${ }^{20}$ SELIGMANN-SILVA. Reflexões sobre a memória, a história e o esquecimento, p. 65.

${ }^{21}$ BOSI. Brás Cubas em três versões: estudos machadianos, p. 53-54.

${ }^{22}$ BOSI. Brás Cubas em três versões: estudos machadianos, p. 54.

${ }^{23}$ BOSI. Brás Cubas em três versões: estudos machadianos, p. 54.

${ }^{24}$ Ver, anexo, a crônica d'“A Semana” de 2 de junho de 1895.

${ }^{25}$ BOSI. Brás Cubas em três versões: estudos machadianos, p. 55.

${ }^{26}$ MARCONDES. Machado de Assis: exercício de admiração, p. 95.

${ }^{27}$ BOSI. Brás Cubas em três versões: estudos machadianos, p. 55.
} 
A memória na crônica machadiana nunca vem desacompanhada do esquecimento, do Lethes. Esse aspecto também é assinalado por Alfredo Bosi, para quem o fluir dos sucessos para o Lethes é estrategicamente trabalhado pelo discurso machadiano das gerações: "Afinal, les mortes vont vites ["os mortos vão depressa"] (frase recorrente nas crônicas [...]), e os jovens não guardam memória deles. ${ }^{, 28}$ Segundo César Guimarães, o que salva a memória não é a estocagem, mas o esquecimento. ${ }^{29}$ Em contraposição à estocagem - lenta ou veloz, sempre sem perdas -, o esquecimento seria "aquilo que provoca a colisão das imagens". 30 "É o esquecimento que desperta a virulência das imagens, sua expansão desordenada, caótica”, argumenta o autor de Imagens da memória. Além disso, não tem a rememoração a pretensão de preencher os buracos da memória, mas de revelar os "pontos decisivos da história do sujeito". ${ }^{31}$ Certamente, esse é um dos aspectos que garante, de alguma forma, a atualidade das crônicas machadianas, lidas com interesse ainda em nosso século.

O discurso machadiano das gerações pode ser aproximado também ao pensamento do filósofo alemão Friedrich Nietzsche, para quem "é totalmente impossível de se viver sem o esquecimento" e que a alegria e a confiança dependem, no indivíduo ou no povo, de que se saiba recordar e esquecer na hora certa. ${ }^{32}$ Outro pensador que pode aqui ser evocado é Walter Benjamin, que no ensaio "Erfahrung und Armut" ["Experiência e pobreza"], de 1933, experimenta um elogio ao esquecimento e critica o interior burguês ao sufocar seus visitantes com o excesso de Spuren, rastros e marcas. ${ }^{33}$ A verdade, nas referidas passagens de Nietzsche, Benjamin - e, segundo nos parece, também na crônica machadiana - não se encontra mais na aletheia ("verdade", em grego), mas em Lethes, no esquecimento. ${ }^{34}$

Outra forma como a memória pode ser analisada na crônica machadiana é a chamada "memória do belo", memória tão cara ao cronista que é capaz de reduzir a "nadas fastientos" as questões econômicas, também por vezes presentes em suas crônicas - como os vaivéns da Bolsa, as jogatinas do Encilhamento, etc. ${ }^{35}$ Em crônica de 26 de abril de 1896, o cronista

\footnotetext{
${ }^{28}$ BOSI. Brás Cubas em três versões: estudos machadianos, p. 55.

${ }^{29}$ GUIMARÃES. Imagens da memória: entre o legível e o visível, p. 16.

${ }^{30}$ GUIMARÃES. Imagens da memória: entre o legível e o visível, p. 16.

${ }^{31}$ GUIMARÃES. Imagens da memória: entre o legível e o visível, p. 16.

${ }^{32}$ SELIGMANN-SILVA. Reflexões sobre a memória, a história e o esquecimento, p. 61.

${ }^{33}$ SELIGMANN-SILVA. Reflexões sobre a memória, a história e o esquecimento, p. 61.

${ }^{34}$ SELIGMANN-SILVA. Reflexões sobre a memória, a história e o esquecimento, p. 61.

${ }^{35}$ BOSI. Brás Cubas em três versões: estudos machadianos, p. 74. Em "Bons dias!", por exemplo, nosso levantamento temático apontou duas crônicas que privilegiam de alguma forma aspectos econômicos. Entretanto, pelo menos na referida série, as referências a políticos e suas histórias
} 
"resenha com desdém as turbulências" da política internacional, ${ }^{36}$ mas outro é seu sentimento quando fala da celebração inglesa a William Shakespeare:

"Terminaram as festas de Shakespeare..." O telegrama [de Londres, 24 de
abril] acrescenta que o delegado norte-americano teve grande manifestação
de simpatia. A doutrina Monroe, que é boa, como lei americana, é cousa
nenhuma contra esse abraço das almas inglesas sobre a memória do seu
extraordinário e universal representante. Um dia, quando já não houver
império britânico nem república norte-americana, haverá Shakespeare;
quando se não falar inglês, falar-se-á Shakespeare. Que valem então todas as
atuais discórdias? O mesmo que as dos gregos que deixaram Homero e os
trágicos. (...) Que vale a caixa egípcia ao pé dos três mil ducados de
Shylock? O próprio Egito, ainda que os ingleses cheguem a possuí-lo, que
vale ao pé do Egito da adorável Cleópatra? Terminaram as festas da alma
humana. ${ }^{37}$

A memória do belo, ou da força, a memória das grandes obras da arte e da poesia, resiste ao esvaziamento de sentido da História, conclui Alfredo Bosi em comentário a essa crônica. ${ }^{38}$ Apenas Homero, os trágicos e Shakespeare podem preencher "os valores autênticos a que se pode aspirar a alma humana". ${ }^{39}$ De acordo com a análise de Bosi, "o que sustenta o valor da obra de ficção é o seu firme nexo com a força, a verdadeira rainha do mundo, na palavra grave de Pascal [filósofo constantemente lido por Machado de Assis] (...) Só a força, causa primeira da existência, não passa", ${ }^{40}$ ainda que passem impérios e línguas. Segundo a análise do crítico, a memória do belo, "por atalhos obscuros, talvez inconscientes, atingiu o segredo da força e o revelou sob as espécies da forma artística. Arte: força criadora de formas." 41

Um contraponto interessante a essa questão está na série "Bons dias!”, a que voltamos, já caminhando para a conclusão deste estudo. Trata-se da consciência da própria finitude, sentimento que não escapa à percepção do cronista: à medida que a consciência da mortalidade mina o ofício poético, "também as suas ficções acabam perdendo o viço das antigas sagas e epopéias, cobrindo-se agora com o véu da melancolia",42 -, observa Alfredo

ainda ocorrem de forma bem mais numerosa, o que pode indicar um apreço maior do cronista pelas aparições ora patéticas e ora risíveis dos homens públicos.

${ }^{36}$ BOSI. Brás Cubas em três versões: estudos machadianos, p. 74-75.

${ }^{37}$ ASSIS. Machado de Assis: obra completa, acesso on-line.

${ }^{38}$ BOSI. Brás Cubas em três versões: estudos machadianos, p. 75.

${ }^{39}$ BOSI. Brás Cubas em três versões: estudos machadianos, p. 75.

${ }^{40}$ BOSI. Brás Cubas em três versões: estudos machadianos, p. 75-76.

${ }^{41}$ BOSI. Brás Cubas em três versões: estudos machadianos, p. 76.

${ }^{42}$ BOSI. Brás Cubas em três versões: estudos machadianos, p. 76-77. 
Bosi, recorrendo, entre outros, a Walter Benjamin e György Lukács. O trecho a seguir é da crônica de "Bons dias!" de 26 de agosto de 1888 :

Muita gente ficará confusa com o milhão de séculos de duração da terra. Outros dirão que, se isto não é eterno, não vale a pena escrever nem esculpir ou pintar. Lá eterno, como se costuma dizer, não é; mas aí uns dez séculos, ou mesmo cinco, é o que se pode chamar (com perdão da palavra) um retalho da eternidade.

Nem por isso os nossos políticos escreverão suas memórias, como desejara o Sr. Senador Belisário. Há muitas causas para isso. Uma delas é justamente a falta do sentimento de posteridade. Ninguém trabalha, em tais casos, para efeitos póstumos. (...) Memórias pessoais para um futuro remoto, é muito comprido. E quais sinceras? Quais completas? Quais trariam os retratos dos homens, as conversações, os acordos, as opiniões, os costumes íntimos, e o resto? Que era bom, era; mas, se isto acaba antes de um milhão de séculos? ${ }^{43}$

Se o narrador moderno encontra-se na prosaica condição de ter consciência da própria finitude, não menos certo é o fato de que a escrita de memórias pessoais fica comprometida, e isso parece angustiar o cronista. A memória da força aqui passa a ser a força da memória. Conforme demonstrou Maurice Halbwachs, não se pode distanciar a memória individual das memórias coletivas - o indivíduo isoladamente não tem controle sobre o resgate do passado. ${ }^{44}$ Para Jean Duvignaud, em prefácio à obra A memória coletiva, de Halbwachs, "a rememoração pessoal situa-se na encruzilhada das malhas de solidariedades múltiplas dentro das quais estamos engajados". ${ }^{45}$ Assim, torna-se possível pensar que, quando fala de memórias pessoais, o cronista também se refere, implicitamente, a memórias coletivas. A memória individual "não está inteiramente isolada e fechada", aponta Maurice Halbwachs, pois um homem, ao evocar seu passado, "tem freqüentemente necessidade de fazer apelo às lembranças dos outros". 46

Ao fazer uso da alteridade, o homem, escrevendo suas recordações, estaria provando da força que tem a memória de inseri-lo em uma determinada comunidade e poder "pintar" ao outro quando "pinta" a si mesmo. A memória tem uma função social, que é não deixar que algo se perca. ${ }^{47}$ Ao alimentar a história, a memória "procura salvar o passado para servir ao presente e ao futuro", escreveu Jacques Le Goff. ${ }^{48}$ Possivelmente seja essa uma das

\footnotetext{
${ }^{43}$ ASSIS. Bons dias!, p. 166.

${ }^{44}$ ARAÚJO; SANTOS. Memória, história e esquecimento: implicações políticas, p. 97.

${ }^{45}$ DUVIGNAUD. Prefácio, p. 14.

${ }^{46}$ HALBWACHS. A memória coletiva, p. 54.

${ }^{47}$ LE GOFF. História e memória, p. 421.

${ }^{48}$ LE GOFF. História e memória, p. 471.
} 
explicações da "persistência da memória" a que nos referimos no início deste estudo. Num mundo em que os relógios não se acertam, é ilusão se julgar dono do tempo. Enquanto os relógios derretem e se desacertam - seja na crônica de Machado ou na pintura de Dalí permanece íntegro e colabora para libertação humana apenas quem cultiva a memória nesse propósito, oferecendo assim algo de "força" à posteridade. ${ }^{49}$

\section{ANeXo: CRÔNICA D"“A SemanA” DE 2 DE JUNHO de 1895}

Quando me deram notícia da morte de Saldanha Marinho, veio-me à lembrança aquele dia de julho de 1868, em que a Câmara liberal viu entrar pela porta o Partido Conservador. Há vinte e sete anos; mas os acontecimentos foram tais e tantos, depois disso, que parece muito mais.

Os liberais voltaram mais tarde, tornaram a cair e a voltar, até que se foram de vez, como os conservadores, e com uns e outros o Império.

Jovem leitor, não sei se acabavas de nascer ou se andavas ainda na escola. Dado que sim, ouvirás falar daquele dia de julho, como os rapazes de então ouviam falar da Maioridade ou do fim da República de Piratinim, que foi a pacificação do Sul, há meio século.

Certo, não ignoras o que eram as recepções de ministérios ou de partidos, viste muitas delas, e a última há seis anos. Hás de lembrar-te que a Câmara enchia-se de gente, galerias, tribunas, recinto. Na última recepção, em 1889, ouvi que alguns espectadores, cansados de estar em pé, sentaram-se nas próprias cadeiras dos deputados. Creio que antigamente não vinha muita gente ao recinto, mas a população da cidade era muito menor. A estatística é a chave dos costumes. Demais, não esqueças a ternura do nosso coração, a cultura da amizade, o gosto de servir, a necessidade de mostrar alguma influência, e por fim a indignação, que leva um grande número de pessoas a entrar com os ombros. Compreende-se, aliás, a curiosidade pública. O acontecimento em si mesmo era sempre interessante; depois, a certeza de que se não ia ouvir falar de impostos, dava ânimo de penetrar no recinto sagrado. Acrescentai que nós amamos a esgrima da palavra, e aplaudimos com prazer os golpes certos e bonitos.

Também houve aplausos em 1868, como em 1889, como nas demais sessões interessantes, ainda que fossem de simples interpelações - aos ministros. - As galerias não podem dar sinais de aprovação ou reprovação, diziam sonolentamente os presidentes da Câmara. A primeira vez que ouvi esta advertência, fiquei um pouco admirado; supunha que o presidente presidia, e que o mais era uma questão de polícia interior; mas explicaram-me que a mesa é que era a comissão de polícia. Compreendi então, e notei uma virtude da galeria, é que aplaudia sempre e não pateava nunca.

${ }^{49}$ Cf. CAMPOS. Sob o signo de relógios em discrepância: um estudo da série de crônicas "Bons dias!", de Machado de Assis, p. 42-43; LE GOFF. História e memória, p. 471. 
Ouço ainda os aplausos de 1868, estrepitosos, sinceros e unânimes. Os ministros entraram, com Itaboraí à frente, e foram ocupar as cadeiras onde dias antes estavam os ministros liberais. Um destes ergueu-se, e em poucas palavras explicou a saída do gabinete. Não me esqueceu ainda a impressão que deixou em todos a famosa declaração de que a escolha de Torres Homem não era acertada. Zacarias acabava de repeti-la no Senado. Geralmente, as dissoluções dos gabinetes eram explicadas por frases vagas, e porventura nem sempre verídicas. Daquela vez conheceu-se que a explicação era verdadeira. Disse-se então que a palavra fora buscada para dar ao gabinete as honras da saída. Alguém ouviu por esse tempo, ao próprio Zacarias, naquela grande chácara de Catumbi, que desde a quaresma sentia que a queda era inevitável. Grande atleta, quis cair com graça.

ltaboraí levantou-se e pediu os orçamentos. Foi então que desabou uma tempestade de vozes duras e vibrantes. Posto soubesse que se despedia a si mesma, a Câmara votou uma moção de despedida ao ministério conservador. Um só espírito supôs que a moção podia desfazer o que estava feito; não me lembra o nome, talvez não soubesse ler em política, e daí essa credulidade natural, que se manifestou por um aparte cheio de esperanças.

Uma das vozes duras e vibrantes foi a de Saldanha Marinho. Escolhido senador pelo Ceará, nessa ocasião, bastava-lhe pouco para entrar no Senado - para esperá-lo, ao menos. O silêncio era o conselho do sábio. Diz um provérbio árabe que - da árvore do silêncio pende o seu fruto, a tranqüilidade . Diz mal ou diz pouco este provérbio, porque a prosperidade é também um fruto do silêncio. Saldanha Marinho podia calar-se e votar, - votar contra o ministério, incluir o nome entre os que o recebiam na ponta da lança, e até menos. Crises dessas alcançam as pessoas. Também se brilha pela ausência. O senador escolhido deitou fora até a esperança. Ergueu-se, e com poucas palavras atacou o ministério e a própria coroa; lembrou 1848, a que chamou estelionato, e deixou-se cair com os amigos. O Senado anulou a eleição, e Saldanha Marinho não tornou na lista tríplice.

Caiu com os amigos. A ação foi digna e pode dizer-se rara. Para ir ao Senado, não faltavam seges, nem animais seguros. Saldanha ficou a pé. Não lhe custava nada ser firme; desde que, em 1860, tornara à política pelo jornalismo, nunca soube ser outra coisa. 1860! Quem se não lembra da célebre eleição desse ano, em que Otaviano, Saldanha e Otoni derribaram as portas da Câmara dos Deputados à força de pena e de palavra? O lencinho branco de Otoni era a bandeira dessa rebelião, que pôs na linha dos suplentes de eleitores os mais ilustres chefes conservadores... Ó tempos idos! Vencidos e vencedores vão todos entrando na história. Alguns restam ainda, encalvecidos ou encanecidos pelo tempo, e dois ou três cingidos de honras merecidas. O que ora se foi, separara-se há muito dos companheiros, sem perder-lhes a estima e a consideração. Mudara de campo, se é que se não restituiu ao que era por natureza. ${ }^{50}$

\footnotetext{
${ }^{50}$ ASSIS. Machado de Assis: obra completa.
} 


\section{ABSTRACT}

Using crônicas of two Machadean series, theorists like Walter Benjamin and Maurice Halbwachs and researchers of crônica, this work aims reflections upon the memory based on Machadean crônica in its specific condition of genre as "written memory" or when it reflects about the memory of the beauty.

\section{Keywords}

Crônica, memory, Machado de Assis, "Bons dias!" [“Good Morning!”], “A Semana" ["The Week"]

\section{REFERÊNCIAS}

ARAUUJO, Maria Paula Nascimento; SANTOS, Myrian Sepúlveda dos. História, memória e esquecimento: implicações políticas. Revista Crítica de Ciências Sociais, n. 79, p. 95-111, dez. 2007. Disponível em: <http://www.ces.uc.pt/rccs/includes/download.php?id=972>. Acesso em: 21 fev. 2012.

ARRIGUCCI JÚNIOR, Davi. Enigma e comentário: ensaios sobre literatura e experiência. São Paulo: Companhia das Letras, 1987.

MACHADO DE ASSIS, Joaquim Maria. Diálogos e reflexões de um relojoeiro: escritos de 1886 (“A+B”), de 1888 e 1889 ("Bons dias"), recolhidos da Gazeta de Notícias. Organização, prefácio e notas de R. Magalhães Júnior. Rio de Janeiro: Civilização Brasileira, 1956.

MACHADO DE ASSIS, Joaquim Maria. Bons dias!. Introdução e notas de John Gledson. 3. ed. Campinas: Editora Unicamp, 2008a.

MACHADO DE ASSIS, Joaquim Maria. Machado de Assis: obra completa. Disponível em: $<$ http://machado.mec.gov.br/>. Ministério da Educação, 2008b. Acesso em: 21 fev. 2012.

ATLAN, Henri. Conscience et désirs dans des systèmes auto-organisateurs. In: MORIN, Edgar; PIATELLI-PALMARINI, Massimo (Dir.). L'unité de l'homme: invariants biologiques et universaux culturels. Paris: Seuil, 1974. p. 449-465.

BOSI, Alfredo. Brás Cubas em três versões: estudos machadianos. São Paulo: Companhia das Letras, 2006.

CAMPOS, Alex Sander Luiz. Sob o signo de relógios em discrepância: um estudo da série de crônicas "Bons dias!", de Machado de Assis. 2010. 50 f. Monografia (Graduação em Letras Português) - Centro de Ciências Humanas, Universidade Estadual de Montes Claros, Montes Claros, 2010. Disponível em: <http://pt.scribd.com/doc/63043177/Sob-o-signo-de-relogiosem-discrepancia>. Acesso em: 5 jul. 2011.

DALÍ, Salvador. The persistence of memory. 1931. Óleo sobre tela. 24,1 x $33 \mathrm{~cm}$. In: THE MUSEUM OF MODERN ART (MoMA). The Collection. 2010. Disponível em: $<$ http://www.moma.org/collection/object.php?object_id=79018>. Acesso em: 5 jul. 2011.

DUVIGNAUD, Jean. Prefácio. In: HALBWACHS, Maurice. A memória coletiva. Trad. Laurent Léon Schaffter. São Paulo: Vértice, 1990. p. 9-17. 
FRISON, Samuel; SANSEVERINO, Antônio (Org.). Diálogos sobre a complexidade da crônica na trajetória de Clarice Lispector e Hilda Hilst - duas escritoras - fora de lugar. Revista Teórica Pobres \& Nojentas, set. 2008. Disponível em: $<$ http://revistapobresenojentas.wordpress.com/2008/09/03/dialogos-sobre-a-complexidade-dacronica-na-trajetoria-de-clarice-lispector-e-hilda-hilst- $\%$ E2\%80\%93-duas-escritoras$\%$ E2\%80\%9Cfora-de-lugar\%E2\%80\%9D/>. Acesso em: 11 nov. 2011.

GRANJA, Lúcia. Machado de Assis cronista: primeiros anos. In: DIAS, Tânia; SÜSSEKIND, Flora (Org.). A historiografia literária e as técnicas de escrita: do manuscrito ao hipertexto. Rio de Janeiro: Casa de Rui Barbosa; Vieira \& Lent, 2004. p. 595-608.

GUIMARÃES, César. Imagens da memória: entre o legível e o visível. Belo Horizonte: Editora UFMG, 1997.

HALBWACHS, Maurice. A memória coletiva. Trad. Laurent Léon Schaffter. São Paulo: Vértice, 1990. (Biblioteca Vértice, Sociologia e Política, v. 21)

LE GOFF, Jacques. História e memória. 2. ed. Trad. Bernardo Leitão et al. Campinas: Editora Unicamp, 1992.

LEROI-GOURHAN, André. O gesto e a palavra. Trad. Vítor Gonçalves. Lisboa: Edições 70, 1981-1983. 2 v.

MAGALHÃES JÚNIOR, Raimundo. Prefácio. In: MACHADO DE ASSIS, Joaquim Maria. Diálogos e reflexões de um relojoeiro: escritos de 1886 (“A+B"), de 1888 e 1889 ("Bons dias!"), recolhidos da Gazeta de Notícias. Org. de Magalhães Júnior. Rio de Janeiro: Ediouro, [19--]. p. 15-23. (coleção Prestígio)

MARCONDES, Ayrton. Machado de Assis: exercício de admiração. São Paulo: A Girafa, 2008 .

NEVES, Margarida de Souza. Uma escrita do tempo: memória, ordem e progresso nas crônicas machadianas. In: CANDIDO, Antonio et al. (Org.). A crônica: o gênero, sua fixação e suas transformações no Brasil. Campinas: Editora Unicamp; Rio de Janeiro: Casa de Rui Barbosa, 1992. p. 75-92.

PÉRES, Sávio Passafaro; MASSIMI, Marina (Org.). O conceito de memória na obra de Machado de Assis. Memorandum, v. 15, p. 20-34. Belo Horizonte: UFMG; Ribeirão Preto: USP, 2008. Disponível em: <http://www.fafich.ufmg.br/ memorandum/a15/permas02.pdf $>$. Acesso em: 10 maio 2011.

SELIGMANN-SILVA, Márcio. Reflexões sobre a memória, a história e o esquecimento. In: . (Org.). História, memória, literatura: o testemunho na Era das catástrofes. Campinas: Editora Unicamp, 2003. p. 59-89. 